\title{
A NEW SPECIES OF NEBRIA LATREILLE, 1802 FROM THE MONTES DE LEÓN, NORTH-WEST SPAIN (COLEOPTERA, CARABIDAE, NEBRIINAE) ${ }^{1}$
}

\author{
T. Aßmann (*), D. W. Wrase $(* *)$ \& J. P. Zaballos $(* * *)$
}

\begin{abstract}
Nebria leonensis sp. n. from the Sierras de la Cabrera Baja and del Teleno (southern Montes de León) is described. This species, related to N. lafresnayei Serville, 1821, is characterised by its slender body, long and light brown extremities, the form of its pronotum, and evenly rounded elytra, which are conspicuously flattened on the discus. The differentiating characters and the habitat are described. A determination key to the species and subspecies of the group to which the new species belongs is presented.
\end{abstract}

Key words: Coleoptera, Carabidae, Nebria, N. lafresnayei group, new species, northwest Spain, endemics, determination key.

\section{RESUMEN}

\section{Nueva especie de Nebria Latreille, 1802 de los Montes de León, noroeste de} España (Coleoptera, Carabidae: Nebriinae)

Se describe Nebria leonensis sp. n. de las sierras de la Cabrera Baja y del Teleno (sur de los Montes de León). Esta especie, relacionada con Nebria lafresnayei Serville, 1821, se caracteriza especialmente por su cuerpo delgado, largas extremidades de color marrón claro, forma del pronoto, y élitros uniformemente redondeados y claramente deprimidos en el disco. Además de describir los caracteres que la definen y el hábitat, se presentan unas breves notas sobre la historia faunística de los montes de León, y una clave de determinación de las especies y subespecies del grupo al que pertenece la nueva especie.

Palabras clave: Coleoptera, Carabidae, Nebria, grupo de N. lafresnayei, nueva especie, noroeste de España, endemismos, clave de determinación.

\section{Introduction}

The northern part of the Iberian Peninsula is colonised by species of the Nebria lafresnayei group which are endemic in one or few massifs (de Miré, 1964; Zaballos \& Jeanne, 1994). The closely related taxa are difficult to distinguish and their distribution, taxonomy, and systematics have not yet been sufficiently investigated. De Miré (1964) described the species and subspecies of this group and presented a determination key. The plurisetose abdominal sternites III to V, the metepisternum that is longer than wide, a slender body with long extremities, and the strongly constricted neck of the head are used as important differentiating characters for 1 of the 2 subgroups. In the Iberian Nebria

This work is supported by the Spanish investigation project: DGES PB 95-0235 (Fauna Ibérica IV).

* Mailing address: Department of Ecology, Faculty of Biology/Chemistry, University of Osnabrück, Barbarastr. 11, D-49069 Osnabrück, Germany. E-Mail: ASSMANN@biologie.uni-osnabrueck.de

** Dunckerstr. 78, D-10437 Berlin, Germany.

*** Departamento de Biología Animal I, Facultad de Biología, Universidad Complutense de Madrid, Ciudad Universitaria s/n, 28040 Madrid, Spain. 
fauna, this combination of characters is restricted to 2 species which are distributed in the Cantabrian mountains and the Pyrenees (and in a small region in the southern part of the French Massif Central; Bonadona, 1971): N. lafresnayei Serville, 1821 and $N$. andarensis Bolívar, 1923. Bänninger (1925) gave further characters for a group containing these 2 species and additional ones from the Caucasus (e.g. base of the hind coxa with 1 seta, penultimate segment of labial palpi with 4 setae). Now a new Spanish species of this subgroup of the $N$. lafresna yei group has been found, but its range is located further south in the southern parts of the Montes de León. In this paper the new species and its habitat are described, and a determination key to the species and subspecies of the $N$. lafresnayei subgroup is presented.

\section{Material and methods}

During several excursions between 1996 and 2000, the southern Montes de León were visited to investigate the carabid fauna in the upper parts (mainly the subalpine zone) of the mountains. The results of these excursions form the basis of the description of the new species of Nebria and of the faunistical records of the endemic ground beetle fauna.

The following ectoskeletal characters were measured to describe the morphometric differentiation between the species of the $N$. lafresnayei s.str. group: (1) elytral length (EL): distance from the tip of the scutellum to the apex of the right elytron, measured parallel to the suture; (2) maximum elytral width (EW): maximum width of the right elytron, measured perpendicular to the suture; (3) maximum prothoracic width $(\mathrm{PW}) ;(4)$ anterior prothoracic width (AW): width joining the two most anterior points of pronotum; (5) body length (BL): distance from the tip of the mandibles to the apex of the right elytron.

All measurements were made using a calibrated ocular micrometer, set in a dissecting microscope ocular (Leica MZ 6). Measurements were taken on body parts held horizontally at 8 to 40 power magnifications.

\section{Nebria leonensis sp. n.}

TyPe MATERIAL: Holotype: male, "Spain (León), Sierra de la Cabrera Baja, ca. $3 \mathrm{~km} \mathrm{~W}$ Mt. Cerro Fallanquinos, $2000 \mathrm{~m}$ (edge of snow fields), 10.VII.1996, D.W. Wrase". Paratypes: 2 males, 1 female, "Spain (León), Sierra de la Cabrera Baja, Vizcodillo, 2050 m, 23.V.1999, leg. W. Starke \& Th. Aßmann"; 4 females, 1 male: "Spain (León), Sierra de la Cabrera Baja, Vizcodillo, 2050 m, 10.VI.2000, leg. W. Starke, P. Hrusa, D.W. Wrase \& Th. Aßmann"; 1 female, "Spain (León), Sierra del Teleno, Cerro del Picón, 2000 m, 22.V.1999, leg. Th. Aßmann".

Holotype in the collection of D.W. Wrase (Berlin, Germany) will be deposited in the collections of the Naturkundemuseum Erfurt (Erfurt, Germany), paratypes in the collections of the Museo Nacional de Ciencias Naturales de Madrid (MNCN Catalogue No.: 8656), in the Zoologische Staatssammlung in Munich and in the collections of W. Starke (Warendorf, Germany), P. Hrusa (Saarlouis, Germany), D.W. Wrase and Th. Aßmann (Bissendorf, Germany).

Diagnosis: An apterous, depressed and slender brown-coloured species of the Nebria lafresnayei group. Distinct within the group due to its flat body, plurisetous abdominal sternites III to $\mathrm{V}$, strongly punctated cordiform pronotum with nearly parallel margins in the basal part and only slightly prolonged hind angles, elytral shoulder strongly rounded, elytral striae clearly punctated, but with flattened intervals.

DESCRIPTION: Habitus as in Fig. 1. BL: 10.8$13.0 \mathrm{~mm}$ (females: $11.6 ; 11.8 ; 12.5 ; 12.5 ; 12.9$; 13.0; males: $10.8 ; 12.0 ; 12.0 ; 11.7$ [holotype]). Body middle-brown, appendages light brown, suture and margin of the elytra brightened up. Upper side with a fine microsculpture of isodiametric meshes.

Head relatively small. Eyes protruding. Temples slightly constricted behind the eyes, in the basal part more parallel. In the anterior part of the frons two impressions showing a confluent, wrinkled punctation. Antennae longer than two-thirds of body length; segment I thick, with 1 or 2 setae; segment III more than twice as long as the second, segment IV twice as long as the second. Penultimate segment of labial palpi with 4 setae. 6 or 8 setae in the gular row. Mentum with two acute teeth (Fig. 2).

Pronotum cordiform (Fig. 6b); sides in the anterior two-thirds evenly rounded, in the basal third more or less parallel, immediately in front of the hind angles slightly constricted. Anterior and posterior angles acute, the latter one projecting backwards, therefore the hind margin is concave. Lateral bead pulled up, with a seta at the maximum width (end of the anterior third) and at the hind angles; median sulcus developed; outer parts strongly punctated, inner ones not or only slightly punctated.

Elytra ellipsoidal and slender; especially flattened at the disk (Fig. 3); maximum width at the beginning of the last third; shoulder strongly rounded, 
1

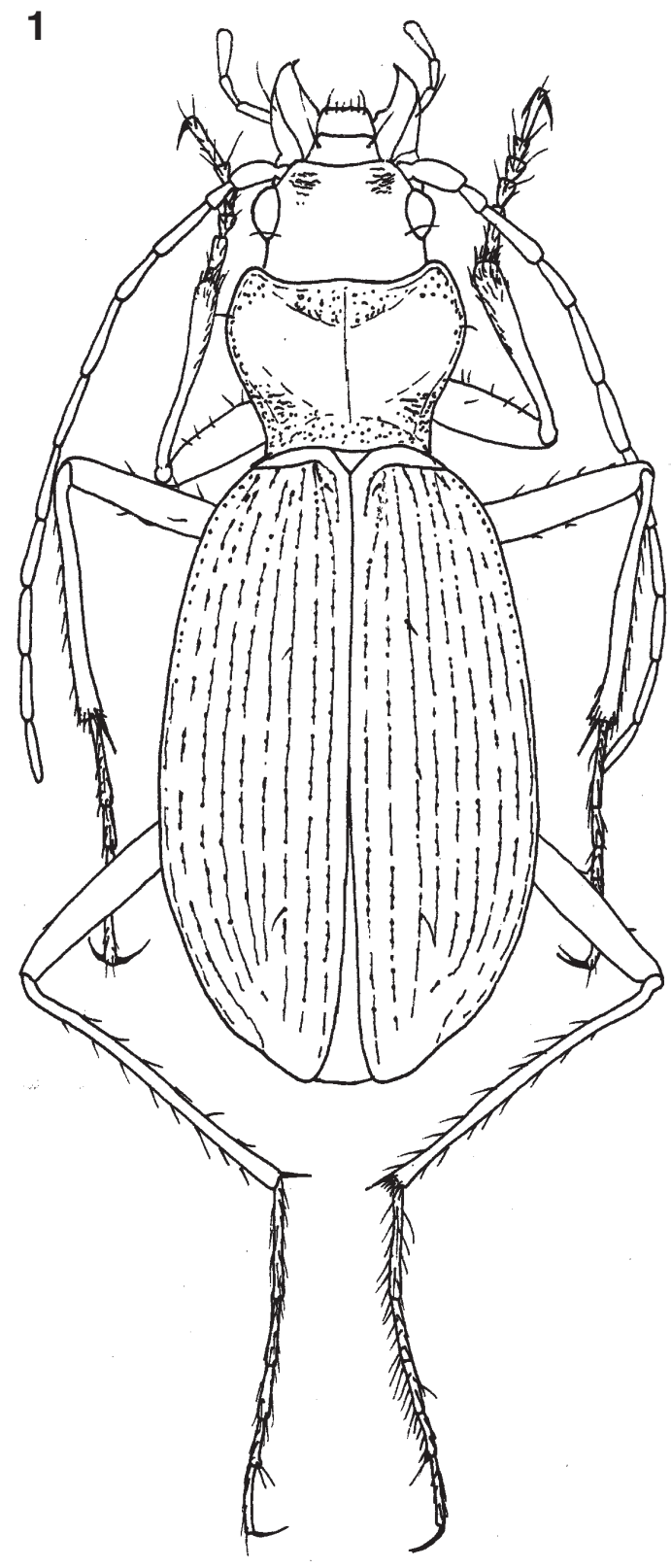

2
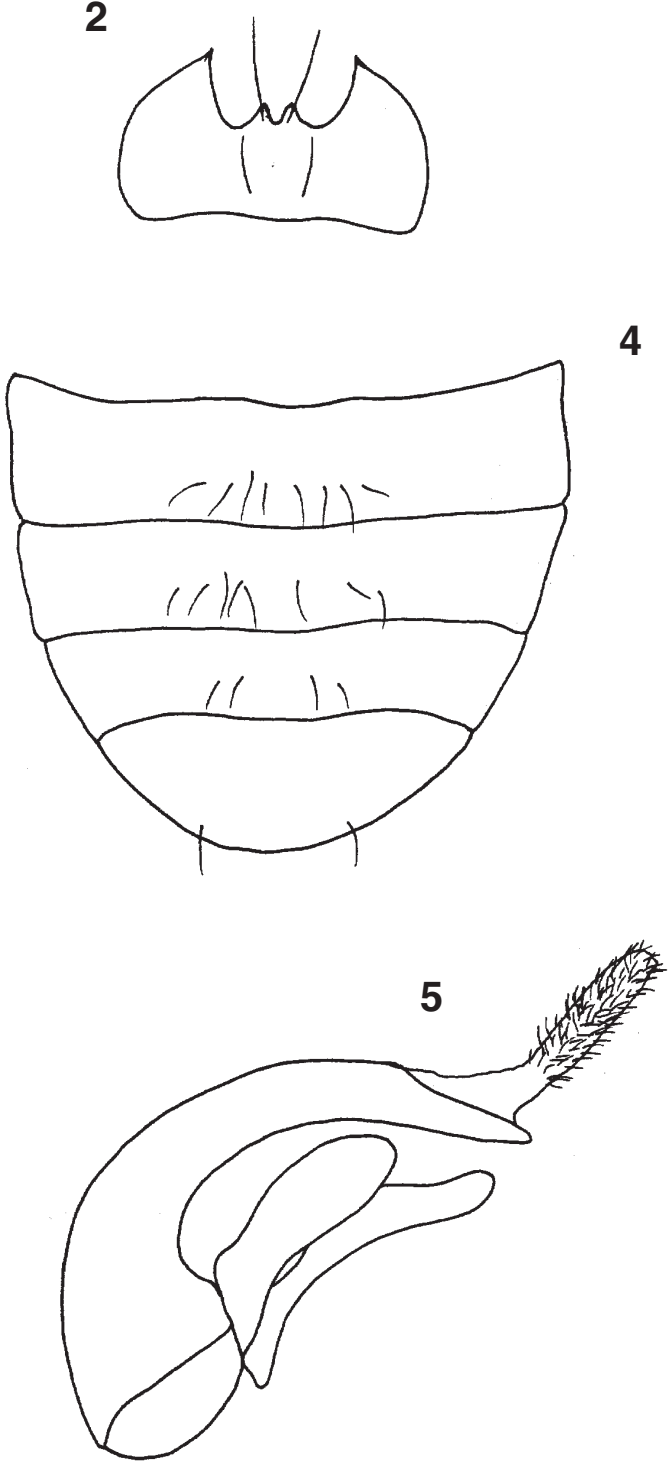

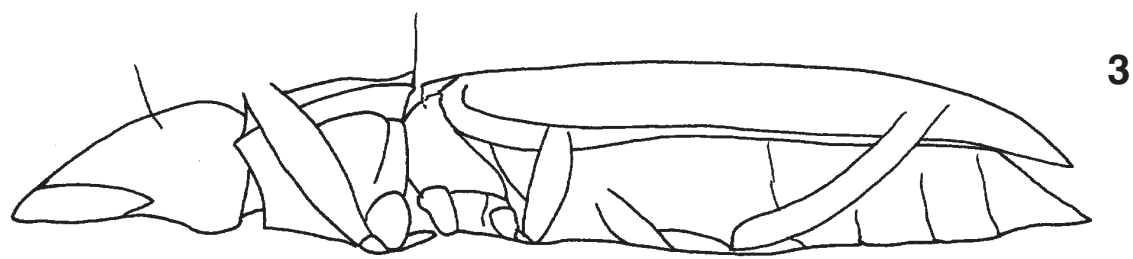

Figs. 1-5.-Nebria leonensis sp. n.: 1) Habitus (holotype); 2) Mentum; 3) Lateral view; 4) Abdominal sternites; 5) Aedeagus.

Figs. 1-5.-Nebria leonensis sp. n.: 1) Habitus (holotipo); 2) Menton; 3) Vista lateral; 4) Esternitos abdominales; 5) Edeago. 


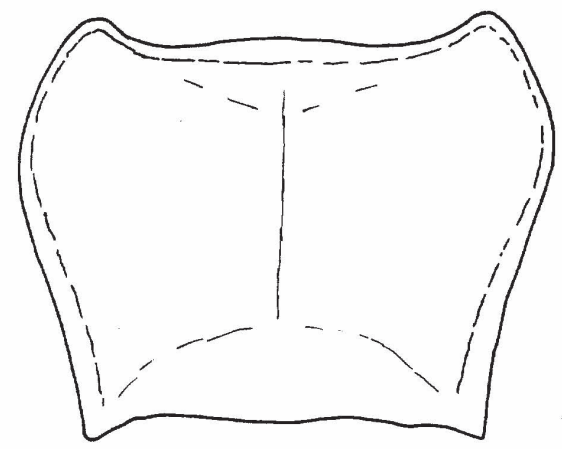

$6 a$

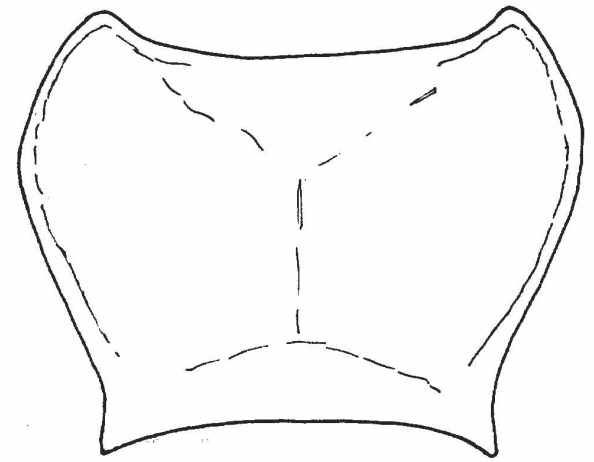

6c

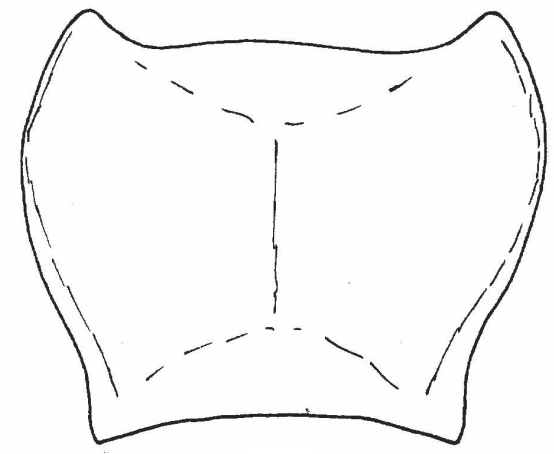

$6 b$

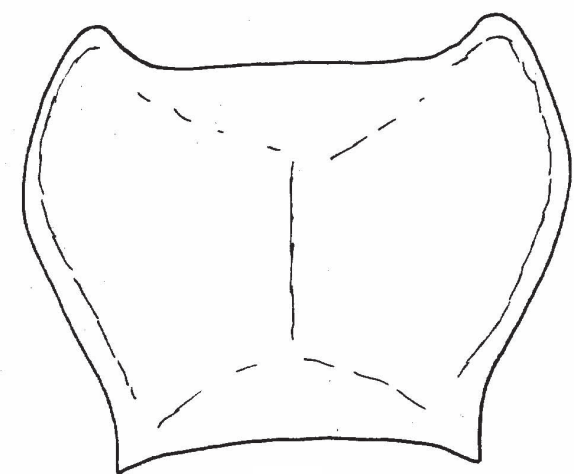

$6 d$

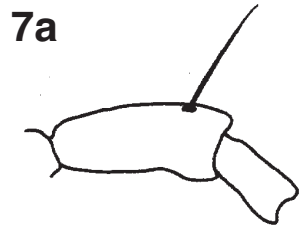

$7 b$

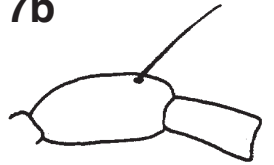

Figs. 6 y 7.-6) Pronotum; a: Nebria andarensis; b: Nebria leonensis sp. n.; c: Nebria lafresnayei s. str.; d: Nebria lafresnayei cantabrica. 7) Antennal segments I and II; a: Nebria lafresnayei ferruginipes; b: Nebria lafresnayei cantabrica.

Figs. 6 y 7.-6) Pronoto; a: Nebria andarensis; b: Nebria leonensis sp. n.; c: Nebria lafresnayei s. str.; d: Nebria lafresnayei cantabrica. 7) Segmentos antenales I y II; a: Nebria lafresnayei ferruginipes; b: Nebria lafresnayei cantabrica. sides evenly rounded (no teardrop form), no humeral tooth, basal margin meets lateral margin; apex of elytra acuminate and gaping; striae deep, clearly punctated, intervals flattened, not convex. Base of stria I with a small scutellar seta; interval III with 2 to 3 setigerous punctures adjoining stria III, their position irregular; basal margin distinct, near the scutellum turned into the scutellar stria which reaches the anterior sixth to fifth of the elytral length; all striae reaching the basal margin. Brachypterous.
Abdominal sternites III to V plurisetose (Fig. 4). Metepisternum is longer than it is wide.

Legs long and slender. Femora only slightly thickened; tarsi and distal part of tibiae pubescent. Lower sides of the distal half of segment I and of the whole segments II and III of tarsi in male with adhesive setae. Segments I to III only slightly enlarged in male. Segment IV of hind tarsi conspicuously projecting backwards on the lower side.

Aedeagus as in Fig. 5. 
ETymology: Named after the region in which the beetles were found (Montes de León).

COMPARISONS: Nebria leonensis sp. $\mathrm{n}$. is a member of the $N$. lafresnayei subgroup; all characters given by Bänninger (1925) and de Miré (1964) are found in the new species. $N$. leonensis $\mathrm{sp}$. n. differs from the other 2 species of this subgroup by the following characters: (1) The body is more slender and especially the discus of the elytra is conspicuously flattened. (2) The elytra are evenly rounded and are not of teardrop form. The quotient EL/EW is greater than $3.0(3.03-3.24)$ for $N$. leonensis sp. n. and smaller than 3.0 for the 2 other species. (3) The appendages are light brown, in contrast to the middle-brown body. (4) The elytral striae are clearly punctated and depressed, but the intervals are flattened.

The pronotum of the new species is similar to that of $N$. lafresnayei (especially of the subspecies $N$. lafresnayei cantabrica), but the anterior angles are more acute and the margin is not so strongly constricted. The quotient PW/AW is 1.30 to 1.34 for $N$. leonensis sp. $\mathrm{n}$. and 1.34 to 1.40 for $N$. lafres nayei cantabrica $(\mathrm{n}=12)$. The new species differs from $N$. andarensis by the lighter colour of its body, the less strongly punctated elytral striae, and the shape of the pronotum. The aedeagus did not show clear differences between the three species (like in many other Nebria species; Lindroth, 1985).

In their determination key to the species of the subgenus Nebria, Ledoux \& Roux (1992) separate $N$. andarensis and $N$. lafresnayei due to the low number of setae on the abdominal sternites III to V(1 seta per segment and side). This statement is not accurate (see also de Miré 1964). Animals from the Picos de Europa massifs El Cornion, Los Urrieles, and Andara showed 2 setae on each side for at least the abdominal segments III and IV ( $\mathrm{n}=12)$. Nebria andarensis must be classified as plurisetose for those abdominal sternites.

Bänninger (1925) emphasised the difficulty to classify the genus Nebria into separate subgenera; $N$. leonensis sp. $\mathrm{n}$. makes this problem even more acute. The subgenus Alpaeus, founded by Bonelli (1810), is redefined by Ledoux \& Roux (1990: 88): "dessus des tarses pubescent, pénultième article des palpes labiaux avec quatre soies au moins et premier article des antennes avec au moins deux soies sur le dessus." The first two characters are also present in $N$. leonensis sp. $\mathrm{n}$., but the latter varies within this species (whereas it varies only slightly or not at all within $N$. lafresnayei and $N$. andarensis: among 75 and 12 individuals studied, respectively, none shows more than 1 seta on the antennal segment I on one or both sides). The typical series of 5 beetles of $N$. leonensis sp. $\mathrm{n}$. contains 1 specimen with 2 setae on both basal antennal segments and 3 specimen showing this character on one side. Since the two first characters are also found in other subgenera, an assignment of $N$. leonensis $\mathrm{sp}$. $\mathrm{n}$. to a subgenus does not seem possible at present.

Following de Miré (1964) and Bänninger (1925), we put together in the N. lafresnayei subgroup Iberian and French Nebria species which show the following characters: (1) plurisetose abdominal sternites III to V (or at least to IV), (2) metepisternum longer than it is wide, (3) slender body with long extremities, (4) strongly constricted neck of the head, (5) base of the hind coxa with 1 seta, (6) penultimate segment of labial palpi with 4 setae, (7) hind tarsal segment IV projecting backwards on the lower side.

\section{Identification key for the Iberian and French species and subspecies of the $N$. lafresnayei subgroup}

1. Pronotum small, the margins are only slightly cordiform, hind angles slightly projecting backwards (Fig. 6a). Marginal bead of the pronotum showing a confluent, wrinkled punctation. Elytral striae strongly punctated. (Picos de Europa) ................................ N. andarensis Bolívar, 1923

* Pronotum larger, more cordiform, hind angles projecting backwards (Figs 6b-d). Marginal bead of the pronotum showing a defined punctation. Elytral striae slightly or moderately punctated

2. Margins of the pronotum are not strongly constricted at the anterior angles, anterior angles acute (Fig. 6b). Elytral striae punctated, their intervals flattened; elytra evenly rounded; EL/EW: 3.03-3.24. Body flat, especially the elytral discus (Fig. 3). Appendages conspicuously light brown. (Southern Montes de León) .... N. leonensis sp. n.

* Margins of the pronotum strongly constricted at the anterior angles, anterior angles more rounded (Figs 6c and 6d). Punctation of elytral striae differing from subspecies to subspecies, the intervals are more convex, not flattened; shoulders more pronounced (EL/EW smaller than 3.0). Appendages are sometimes lighter than the body, but not so conspicuously differentiated ....................................... 3

3. Antennal segment I markedly prolonged (more than 1.5 times as long as the following segment), strongly thickened at the distal end (Fig. 7a). (Eastern Pyrenees, southern parts of the French Massif Central)

* Antennal segment I longer than the following one, but less than 1.5 times, not so strongly thickened at the distal end (Fig. 7b). (Central and western Pyrenees, Cantabrian mountains)

4. Basis of the pronotum weakly punctated. (Southern parts of the French Massif Central)

N. lafresnayei foudrasi Dejean, 1828

* Basis of the pronotum strongly punctated. (Eastern Pyrenees: Massifs de Carlitte, Canigou and Puigmal d'Err) N. lafresnayei ferruginipes Pic, 1903 


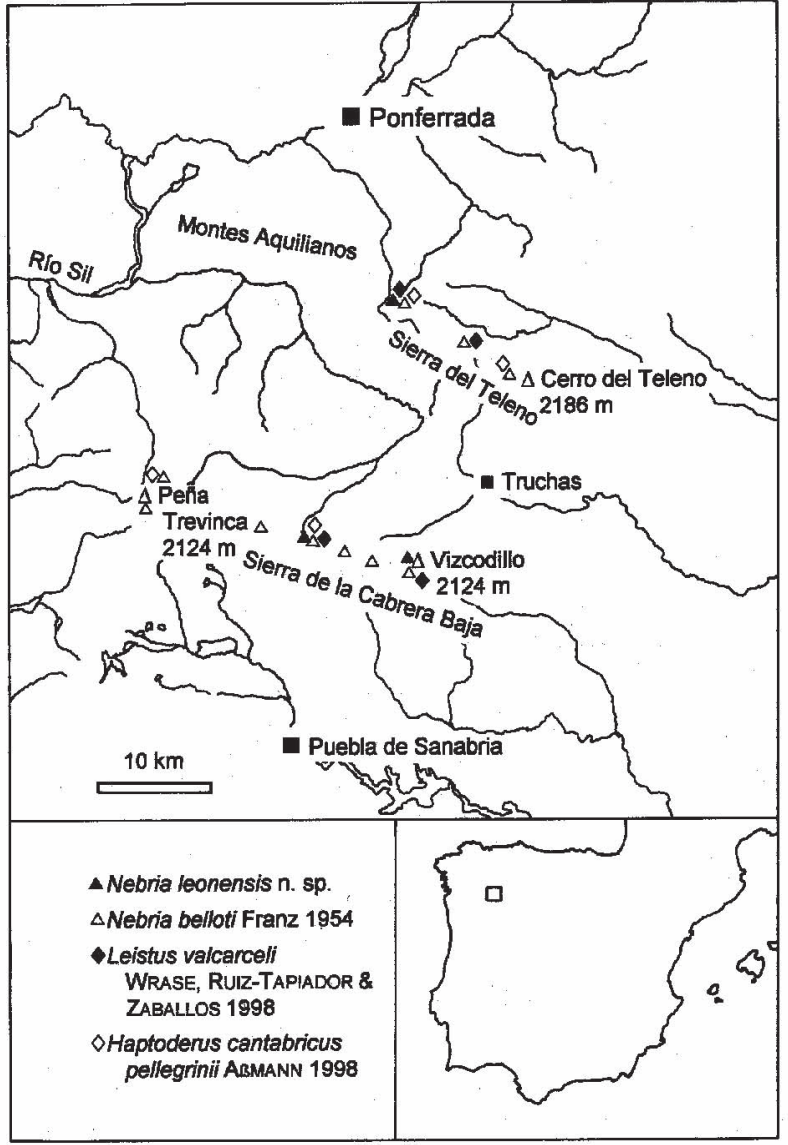

Fig. 8.- Records of ground beetles which are endemic in the Montes de León and have been found in the vicinity of snow fields in the subalpine zone (about $2000 \mathrm{~m}$ above sea-level).

Fig. 8.- Citas de carábidos endémicos de los montes de León, encontrados en las proximidades de los neveros de la zona subalpina (sobre $2000 \mathrm{~m}$ ).

5. Punctation of the elytral striae fine and less deep. Pronotum more strongly constricted at the anterior angles, pronotal margins more angular near the marginal seta and concave before the hind angles (Fig. 6c). (Western and central Pyrenees: from Roncesvalles to Andorra)

N. lafresnayei s. str. Serville, 1821

* Punctation of the elytral striae stronger and deeper. Pronotum not so strongly constricted to the anterior angles, pronotal margins more rounded near the marginal seta and parallel in the basal part, convex just before the hind angles (Fig. 6d). (Cantabrian Mountains)

N. lafresnayei cantabrica de Miré, 1964

HABITAT AND DISTRIBUTION: Nebria leonensis sp. $\mathrm{n}$. is found in the vicinity of snow fields in the subalpine zone (about $2000 \mathrm{~m}$ above sea-level) of two massifs in the southern Montes de León: Sierra del Teleno and Sierra de la Cabrera Baja. These mountains located south and north of La Cabrera are colonised by an endemic ground beetle fauna (with constantly brachypterous species) which seems to be restricted to the surroundings of snow fields: Leistus valcarceli Wrase, Ruiz-Tapiador \& Zaballos, 1998 is described from the Cerro Fallanquinos in the Sierra de la Cabrera Baja. Additional records are also known from another peak of this massif and from the Sierra del Teleno (Fig. 8). Nebria belloti Franz, 1954 and Haptoderus cantabricus pellegrinii Aßmann, 1998 also live exclusively in both massifs (Franz, 1979; Alonso et al., 1987; Fig. 8).

Specimens of these species have not yet been detected in lower altitudes, in spite of great sampling efforts. Both mountains are separated by the rivers Río Cabrera and Río Ería, which cut deep valleys into the massifs. The distribution of the above-mentioned species supports the theory that a connection between both mountains existed in the past. The occurrence of mixed woodlands and coniferous stands in north-west Spain during the peak of the last glaciation (Castro et al., 1997) implies that ground beetles which adapted to cold places above the timberline could survive within the same massifs (or in their close neighbourhood). Additional discussions about the mountains in north-west Spain acting as Pleistocene refugia (socalled "massifs de refuge") during the glacial periods have been put forward by Franz (1963) and Aßmann (1999).

\section{ACKNOWLEDGEMENTS}

We would like to extend special thanks to the following colleagues and friends for their kind help: Benedikt Feldmann (Münster), Fernando Prieto Piloña (Pontevedra), Ildefonso Ruiz-Tapiador (Madrid), Werner Starke (Warendorf near Münster), and Javier P. Valcárcel (La Coruña) for their participation in excursions to the Montes de León, and Martina Lemme and Teresa Gehrs (Osnabrück) for the linguistic revision of the manuscript.

\section{References}

Alonso, M. M., NovoA, F. \& EiroA, E., 1987. Los Carabidae (Coleoptera, Adephaga) de Sierra Segundera y Peña Trevinca (Noroeste de España). I. Estudio faunístico. Boletín de la Real Sociedad Española de Historia Natural (Sección Biológica), 83(1-4): 19-34. 
ABMANN, T., 1998. A new subspecies of Haptoderus (Iberoderus) cantabricus Schaufuss, 1862 (Coleoptera, Carabidae, Pterostichinae). Acta Coleopterologica, 14(1): 47-50.

AßMANN, T., 1999. A new anophthalmic genus of Perigonini from the Iberian Peninsula (Insecta, Coleoptera, Carabidae). Spixiana, 22: 255-262.

BALKENOHL, M., 1999. Reicheiodes microphthalmus (Heyden 1870) from the north-western Iberian peninsula, with a description of the new subspecies Reicheiodes microphthalmus assmanni ssp. n. (Coleoptera: Carabidae, Scaritinae). Beiträge zur Entomologie, 49: 389-397.

BÄNNINGER, M., 1925. Neunter Beitrag zur Kenntnis der Carabinae: die Nebriini. Entomologische Mitteilungen, 14(2): 180-195, 14(3/4): 256-281, 14(5/6): 329-341.

Bonadona, P., 1971. Catalogue des Coléoptères Carabiques de France. Nouvelle Revue d'Entomologie, Suppl.: 1-177.

Bonelli, F. A., 1810. Observations Entomologiques (Première Partie). Mémoires de l'Académie Impériale des Sciences, Littérature et Beaux-Arts de Turin, 1809: 42-58.

Castro, E. B., Gonzalez, M. Á. C., Tenorio, M. C., Bombín, R. E., Antón, M. G., Fuster, M. G., Manzaneque, Á. G., Manzaneque, F. G., Saiz, J. C. M., Juaristi, C. M., Pajares, P. R. \& Ollero, H. S., 1997. Los bosques ibéricos: una interpretación geo botánica. Planeta. Barcelona. 572 pp.

DE Miré, Ph. B., 1964. Essai d'interprétation de la variation géographique et la spéciation chez les Nebria orophiles du nord-ouest de la Péninsule Ibérique. Revue Française d'Entomologie, 31(1): 18-35.

Franz, H., 1963. Die hochspezialisierten terrikolen Coleopteren der iberischen Halbinsel als Indikatoren natürlichen Waldlandes. Eos (Madrid), 39: 221-255.
FrANZ, H., 1979. Ökologie der Hochgebirge. Ulmer. Stuttgart. 494 pp.

Ledoux, G. \& Roux, P., 1990. Le genre Nebria (Coléoptères, Nebriidae) I. Redéfinition des sousgenres Alpaeus et Nebria; description de sept espèces et d'une sous-espèce nouvelles de Turquie. L'Entomologiste (Paris), 46(2-3): 65-97.

Ledoux, G. \& Roux, P., 1992. Le genre Nebria (Coléoptères, Nebriidae) II. Compléments sur le sous-genre Alpaeus et analyse du sous-genre Nebria. L'Entomologiste (Paris), 48(5): 241-264.

Lindroth, C.H., 1985, 1986. The Carabidae (Coleoptera) of Fennoscandia and Denmark. Fauna Entomologica Scandinavica, 15: 1-497.

Wrase, D. W., Ruiz-Tapiador, I. \& Zaballos, J. P., 1998. Description of a new Leistus from the Sierra de la Cabrera Baja in north-west Spain (Carabidae, Nebriini). Linzer biologische Beiträge, 30(1): 201205.

Zaballos, J.P. \& JeAnne, C., 1994. Nuevo Catálogo de los Carábidos (Coleoptera) de la Península Ibérica. Monografias Sociedad Entomológica Aragonesa, 1: $1-159$. 